\title{
Fausto Silvério Monteiro, o Fininho: um artista gráfico a serviço do cinema pernambucano do Ciclo do Recife
}

\section{Fausto Silvério Monteiro, Fininho: a graphic artist working for Pernambuco's first cinema cycle}

\author{
Larissa Constantino Martins de Oliveira, Universidade Federal de Pernambuco \\ larissacmo@gmail.com
}

\author{
Isabella Ribeiro Aragão, Universidade Federal de Pernambuco \\ isabella.aragao@ufpe.br
}

\begin{abstract}
Resumo
O Ciclo do Recife foi um movimento de produção de cinema que ocorreu na capital pernambucana durante a década de 1920. Entre o seleto grupo de profissionais não especializados na área cinematográfica, encontrava-se Fausto Silvério Monteiro, conhecido como Fininho. Por ter sido responsável pelas ilustrações das cartelas de, pelo menos, dois filmes silenciosos do Ciclo do Recife - Aitaré da praia (1925) e A filha do advogaodo (1926) - ele pode ser considerado como um dos primeiros artistas gráficos a prestar serviço para o cinema brasileiro. Por meio de uma abordagem histórico/analítica focada em sua trajetória como artista gráfico dos filmes e de sua produção como caricaturista nos periódicos recifenses da década de 1920, refletimos sobre as representações de regionalismo e modernidade, assim como dimensionamos uma relação intrínseca entre os elementos pictóricos das cartelas com cenas dos filmes.
\end{abstract}

Palavras-chave: Cinema silencioso, Linguagem gráfica, Artes gráficas, História do design brasileiro

\begin{abstract}
The "Ciclo do recife" was a film production movement that took place in the capital of Pernambuco during the 1920s. Among the select group of non-specialized professionals in the cinematographic field, there was Fausto Silvério Monteiro, known as Fininho. Because he was responsible for intertitles' illustrations of at least two silent films of the movement - "Aitaré da praia" (1925) and "A filha do advogado" (1926) - he can be considered as one of the first graphic artists to work for the Brazilian cinema. Through a historical/analytical approach focused on his trajectory as a graphic artist of the films and his production as a caricaturist in Recife's periodicals of the 1920s, we reflect on the representations of regionalism and modernity, as well as we dimension an intrinsic relationship between the pictorial elements of the cards with scenes of the films.
\end{abstract}

Keywords Silent movies, Graphic language, Graphic arts, Brazilian design History. 


\section{Introdução}

O cinema possui uma linguagem híbrida que permite o uso de diferentes elementos para contar uma história. Elementos da linguagem gráfica, por exemplo, palavras escritas, em conjunto com as imagens em movimento, compõem a banda visual da linguagem cinematográfica.

O cinema silencioso, foco de nossa exploração, também utilizou a linguagem gráfica como parte de sua narrativa, principalmente, por meio da inserção de letreiros (ou cartelas) entre as cenas. Assim, as informações nas cartelas comunicavam ao expectador dados sobre a história que muitas vezes as imagens não conseguiam informar.

Embora as investigações que relacionam as áreas do design gráfico e do cinema tenham sido realizadas por diversos pesquisadores ao longo dos anos, por exemplo, Aragão (2006) e Machado (2020); não encontramos nenhuma pesquisa de design especificamente sobre o cinema silencioso no Brasil. Com esta investigação buscamos ampliar os debates que relacionam as duas áreas ao analisar os filmes Aitaré da praia (1925) e A filha do advogado (1926), considerados clássicos do Ciclo do Recife: movimento regional de produção cinematográfica que aconteceu na década de 1920 em Pernambuco.

Além disso, é de grande importância investigar como ocorreram os processos de produção de cinema fora do grande circuito norte-americano e europeu. A pesquisa igualmente contribui com investigações acerca dos meios de produção e as relações entre artista gráfico e cinema, já que Fausto Silvério Monteiro, o Fininho, foi o artista responsável pelos elementos pictóricos dos letreiros dos filmes. Como ele é um dos primeiros artistas gráficos que projetou cartelas para os filmes do cinema silencioso no Brasil, e ainda não foi devidamente estudado, a pesquisa também tem um caráter inovador nesse aspecto.

A investigação histórica sobre o artista gráfico, que não pretendeu ser exaustiva, se sucedeu por meio de pesquisa na Biblioteca do Estado de Pernambuco (BPE); na Vila Digital e na Cinemateca Pernambucana, pertencentes a Fundação Joaquim Nabuco; além dos acervos online da Hemeroteca Digital da Biblioteca Nacional, da Fundação Joaquim Nabuco e do Portal Domínio Público. Nesta fase, também observamos periódicos que circulavam na cidade do Recife na década de 1920 (A Pilheria, Diário de Pernambuco, Jornal do Recife, Revista da Cidade, Revista do Norte e Rua Nova) e algumas revistas de outros estados que veicularam informações sobre os filmes da amostra, como as revistas Cinearte (RJ) e Para Todos (RJ).

Os filmes, por outro lado, passaram por um processo de observação sistemática à luz da abordagens analíticas das configurações gráficas no cinema realizadas pelas pesquisadoras Aragão (2006) e Machado (2019) no intuito de descrever o sistema e as estratégias da linguagem gráfica utilizados nas narrativas. Por conta do limite textual deste artigo ${ }^{1}$, apresentaremos as reflexões relacionadas com os elementos pictóricos das cartelas dos filmes para, assim, tecer relações com a estética de Fininho e refletir sobre a representação da modernidade e regionalismo nos filmes recifenses.

\footnotetext{
${ }^{1}$ Este artigo apresenta um recorte dos resultados da pesquisa de mestrado de Oliveira (2020).
} 


\section{Fausto Silvério Monteiro, o Fininho}

Fausto Silvério Monteiro, mais conhecido como Fininho, provavelmente, saiu jovem da Paraíba para morar em Recife no ano de 1922 em busca de um cenário mais propício para executar seu ofício com instrumentos de desenho como o nanquim (DIÁRIO DE PERNAMBUCO, 19 out. 1922, p. 3). Na cidade, além de produzir material gráfico para o cinema pernambucano - Fininho foi responsável pelas ilustrações do cartaz de A filha do Advogado (OLIVEIRA, 2020) - também atuou como renomado caricaturista e chargista.

Fininho expôs seu trabalho de caricatura e charge (DIÁRIO DE PERNAMBUCO, Op. Cit.) em Recife assim que chegou à cidade e antes de consolidar sua atuação na imprensa e no cinema, que exploraremos mais adiante. A exposição com 50 obras inaugurada em 20 de agosto de 1922 na Photographia Piereck, onde trabalhava como auxiliar, foi recebida, em geral, com elogios pelos periódicos da época: o Diário de Pernambuco anunciou que a maioria de suas caricaturas tinham um nível de fidelidade próxima ao retrato (DIÁRIO DE PERNAMBUCO, 27 ago. 1922, p. 3), além de informar o sucesso de venda das obras (DIÁRIO DE PERNAMBUCO, 29 ago. 1922, p. 3); e o Jornal do Recife descreveu Fininho, e o colega Olívio Pinto, como iniciantes, mas "de grande talento e muita vocação para a carreira que abraçaram" (JORNAL DO RECIFE, 23 out. 1922, p. 1). Apesar de enaltecer o trabalho do paraibano, o jornalista que escreveu a nota do Jornal do Recife enxergava o estilo do artista como um defeito:

São muito expressivos e interessantes os seus trabalhos. Só lhe encontramos um defeito: é minucioso demais nos detalhes, o que aliás facilmente se explica atendendo que as suas caricaturas são tiradas de retrato e não dos originais como fazem os mestres e outros amadores dos lápis mais práticos. A julgar pelos seus trabalhos expostos, vemos que Fausto Silvério, com um pouco mais de tempo e convivência com artistas do seu gênero saberá corrigir esse defeito, que não é difícil, e conseguirá alcançar um belo triunfo, pois tem muito jeito para caricatura e apanha com facilidade e grande perfeição os traços fisionômicos de qualquer indivíduo, o que é o principal para vencer na sua carreira. (ibid.)

A crítica, que demonstra uma expectativa estética em relação a seu trabalho, não deve ter atrapalhado sua inserção no circuito artístico e cultural da cidade. Ao contrário, a parceria com o conceituado ateliê de Piereck, - vale ressaltar que o espaço também abrigou exposição do já internacionalmente conhecido pintor Vicente do Rego Monteiro (WANDERLEY, 2020) - deve ter dado visibilidade ao artista visto que um ano depois da exibição ele iniciou uma contribuição com a Revista do Norte. O periódico publicou uma matéria (REVISTA DO NORTE, 9 out. 1923, n.p.) apresentando Fininho como o novo talento que iria integrar o conjunto de artistas parceiros (figura 1): "estampando agora esta excelente auto-caricatura, verdadeira obra prima de semelhança e testemunho do traço elegante e seguro do autor, apresentamos aos nossos leitores mais um caricaturista a dar realce as nossas páginas: Fininho" (ibid.). Embora ele tenha sido anunciado como futuro caricaturista da revista, não encontramos outros registros de caricaturas assinadas por ele nas edições restantes que foram resguardadas pela Biblioteca Pública do Estado de Pernambuco. 


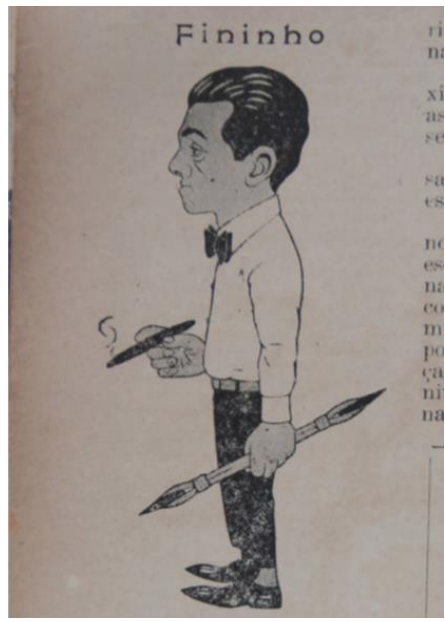

Figura 1: Auto caricatura de Fausto Silvério Monteiro (1923). Fonte: Biblioteca Pública do Estado de Pernambuco.

Fininho, o caricaturista J. Ranulpho - outro importante nome artístico de Recife -, e os principais pintores locais participaram da grande Exposição Geral de Pernambuco, em 1924 (DIÁRIO DE PERNAMBUCO, 25 out. 1924, p.3). Segundo Araújo (2013a), o evento tanto encerrava as comemorações do centenário da Confederação do Equador quanto celebrava 2 anos do governo de Sergio Loreto. Sua participação no meio de "quase três mil produtos pelos 32 salões dos dois andares do Quartel da Força Pública do Estado" (ibid., p.97) demonstra o reconhecimento de sua atuação como artista gráfico em Recife em um evento cujo intuito era "enaltecer as riquezas e o progresso do estado" (ibid.). Como o cinema foi um importante atrativo da exposição e alguns filmes sobre o evento foram financiados por Loreto, é possível vislumbrar alguma relação entre a participação de Fininho na Exposição Geral e no Ciclo do Recife. Será que essa mostra foi determinante para levar seus trabalhos às telas dos cinemas?

No que concerne à imprensa, o artista prestou serviços gráficos para as revistas A Pilhéria, Revista do Norte, Estudantina, Colombina, como destaca Nascimento (1982), além do Jornal do Recife em diferentes anos, pelo que pudemos averiguar. Em fevereiro de 1926, por exemplo, Fininho produziu algumas ilustrações temáticas de carnaval (figura 2) em algumas edições do jornal, como a figura do Arlequim e da Colombina para a primeira página do periódico (JORNAL DO RECIFE, 14 fev. 1926, p. 1). Algumas páginas depois, Fininho ilustrou um homem de sombrinha dançando frevo (ibid., p.4). É importante notar que a representação dos personagens com o rosto desenhado a partir da feição lateral se repete. 

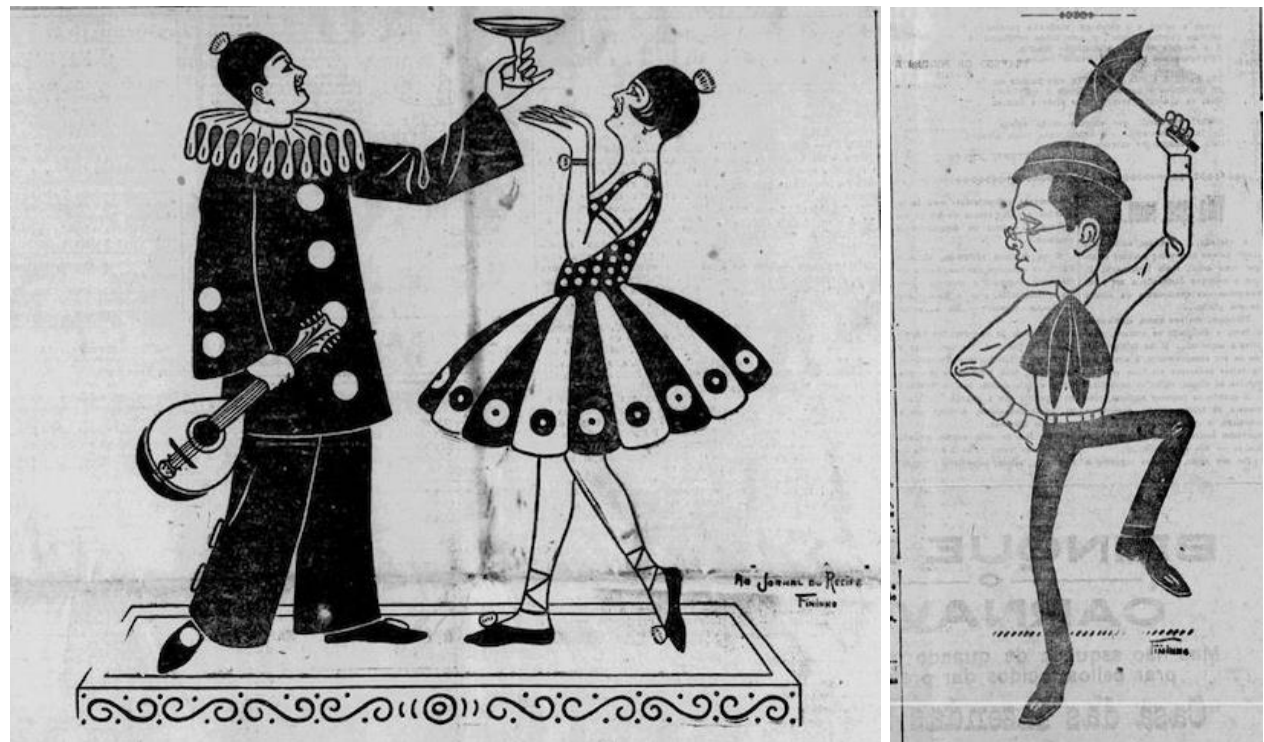

Figura 2: Ilustrações com temática carnavalesca produzidas por Fininho em 14 fevereiro de 1926 para o Jornal do Recife. Fonte: Hemeroteca Digital da Biblioteca Nacional.

Em outra edição do Jornal do Recife (16 fev. 1926, p.3), Fininho ilustrou mais alguns personagens (figura 3). Com exceção da melindrosa tatuada, todos os desenhos são feitos com predominância de contorno sem preenchimento e personagens com perfil lateral.
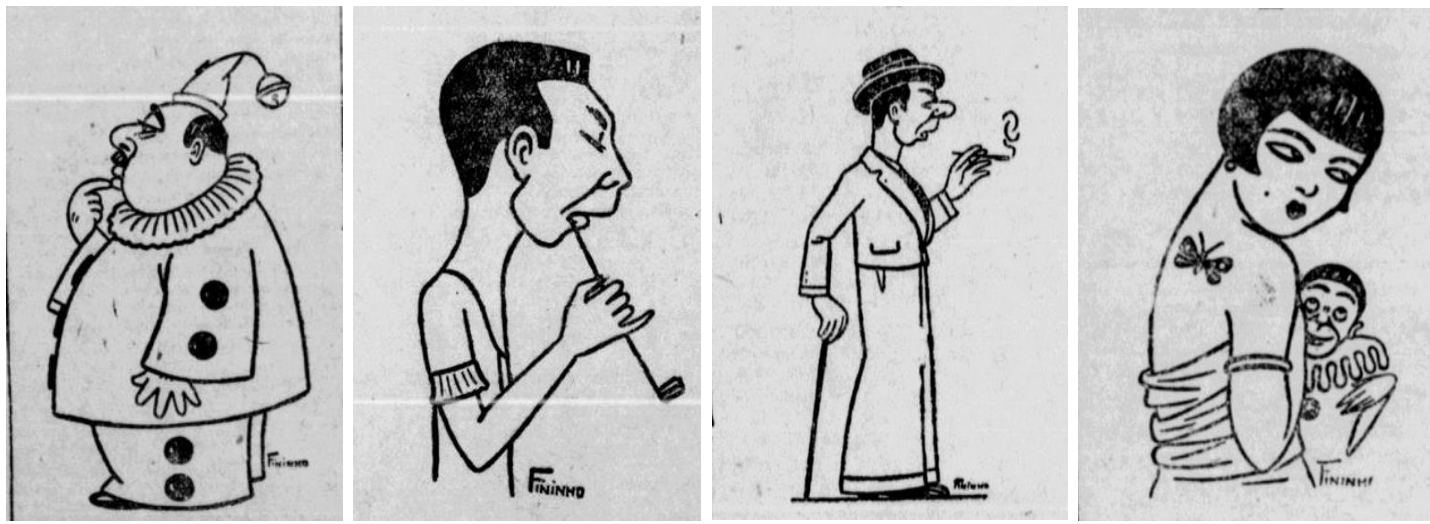

Figura 3: Ilustrações produzidas por Fininho para o Jornal do Recife em 16 de fevereiro de 1926. Fonte: Hemeroteca Digital da Biblioteca Nacional.

A mesma feição lateral, contorno e poucos preenchimentos chapados encontrados nos exemplos citados anteriormente podem ser observadas na caricatura de seu colega artista Baltazar da Câmara (figura 4) para o Jornal do Recife (27 fev. 1927, p.8). Essas obras não aparentam ter sido realizadas com a minúcia de detalhes, citada anteriormente, que foi criticada pelo próprio periódico em 1922. 


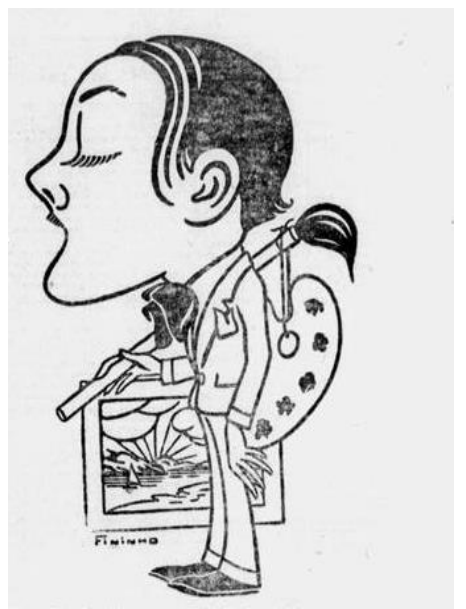

Figura 4: Caricatura do artista Baltazar da Câmara por Fininho para o Jornal do Recife. Fonte: Hemeroteca Digital da Biblioteca Nacional.

Conforme Barros (2015, p. 207), na década de 1920, "a imprensa era a única porta que se abria a esses mestres do desenho. Não havia surgido ainda o uso frequente do desenho técnico nem o seu aproveitamento mais geral nas técnicas de propaganda". No entanto, Fininho complementava o trabalho para a imprensa local com encomendas de caricaturas para qualquer fim, conforme anúncios no Jornal de Recife (10 abr. 1926, p.7) de seus serviços com endereço na Photographia Piereck (figura 5).

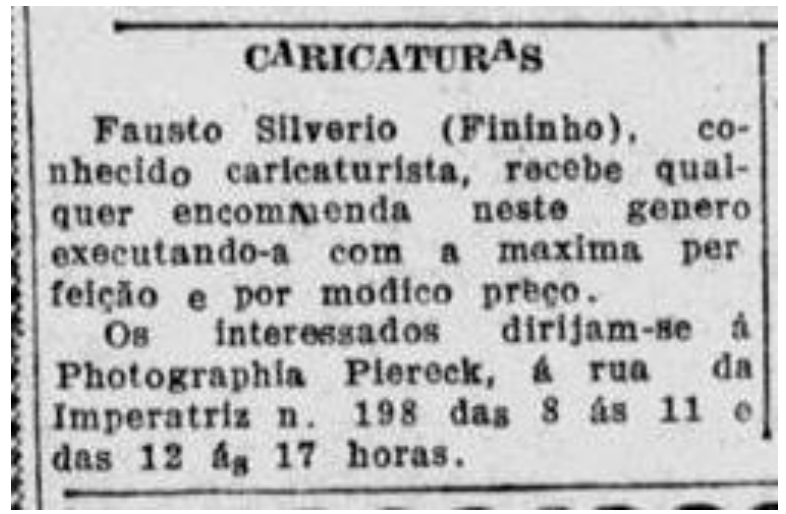

Figura 5: Anúncio no Jornal de Recife indicando que Fininho recebia encomendas de caricaturas. Fonte: Hemeroteca Digital da Biblioteca Nacional

As menções elogiosas a seu talento tecidas pelos periódicos locais, a participação em exposições e os trabalhos executados para a imprensa, entre outros fatores, demonstram que Fininho teve uma carreira de caricaturista consolidada em Recife. Ademais, a longeva parceria com a Photographia Piereck e sua participação nos filmes pernambucanos corroboram com seu prestígio no cenário artístico recifense da década de 1920. Conforme o comentário de Soares (1951), um dos nomes centrais do Ciclo do Recife, o artista também deve ter sido apreciado pelo público cinematográfico: 
O caricaturista Fausto Silvério Monteiro, mais conhecido como Fininho, desenhava as vinhetas $^{2}$ destinadas a enriquecer as legendas dos filmes da Aurora Film, empregando nisso um carinho excepcional em troca de uma remuneração a critério da empresa. O seu trabalho sempre foi muito admirado por aqueles que sabiam enaltecer as boas obras. (SOARES, 1951, p.38)

Para desmentir os boatos sobre o suicídio de Fininho, o Jornal Pequeno (28 mar. 1933, p.4) publicou uma nota para tranquilizar e demonstrar a alegria que o meio artístico recifense sentiu ao saber, pelas mãos do próprio artista em carta direcionada ao proprietário da Electro-Photo, que ele estava residindo em João Pessoa com muita saúde. Seu falecimento em 27 de dezembro de 1935 foi noticiado junto com a descrição de uma pessoa inteligente e trabalhadora pelo Diário da Manhã (29 dez. 1935, p.4).

Apesar de uma carreira bem sucedida, Fininho não chegou a alcançar o prestígio de importantes multiartistas nacionais que igualmente trabalharam para o início do cinema brasileiro, até onde conseguimos averiguar, como Alceu Chichorro para a produtora Groff, de Curitiba, em 1926 (CINEARTE, 17 mar. 1926, p.2); e Belmonte que produziu os letreiros do filme $O$ mysterio do Dominó (1930) para a produtora paulistana Épica Film (CINEARTE, 5 nov. 1930, p.41).

Por ter executado trabalhos que se encaixam na definição de designer de Twyman (1979, p.118, tradução livre) - "designer gráfico significa alguém que planeja a linguagem gráfica" -, abordamos as ilustrações incorporadas nos letreiros à luz de sua teoria.

\section{Linguagem gráfica e configurações gráficas no cinema}

A partir da ausência de um modelo que descrevesse a linguagem gráfica verbal para auxiliar a prática de designers, Twyman (1979) procurou formas de expandir os estudos relacionados ao assunto. Para ele, os estudos que foram formatados até então abordavam de maneira enfática a linguagem verbal por meio da oralidade, deixando de lado a linguagem gráfica verbal e seus modos de expressão. Twyman (1985) também explica que o modo tradicional de divisão da linguagem não acomodava as imagens: "Isso se daria pelo fato de que a linguagem falada - que não tem o modo pictórico - foi o interesse dominante entre os linguistas" (ibid., p.245, tradução livre). A partir de então, o autor definiu que a linguagem gráfica é composta por elementos, feitos à mão ou mecanicamente, dos modos de simbolização verbal, pictórico e/ou esquemático.

Enquanto os modos de simbolização verbal e pictórico são auto-explicativos, o esquemático diz respeito a tudo que não for considerado verbal/numérico ou pictórico (ibid.). Em pesquisa posterior, Aragão (2006) estudou a linguagem gráfica em movimento em filmes do grande circuito comercial dos anos de 1996 até 2006. A autora sugere a utilização do termo configurações gráficas para se referir a "todos os elementos da linguagem gráfica (verbal/numérico, pictórico e esquemático)" (ibid., p.14) utilizados na narrativa dos filmes e defende a ampliação da dimensão gráfica da linguagem cinematográfica para além das "menções escritas" (METZ, 1980), exemplificadas majoritariamente por palavras.

\footnotetext{
2 A palavra vinheta na impressão tipográfica significa tanto os ornamentos, de diversos motivos, fundidos nas peças de metal quanto os desenhos gravados nos clichês
} 
No cinema silencioso, o principal elemento dos letreiros é indubitavelmente o texto escrito, porém outros elementos gráficos, principalmente molduras, também compuseram essas configurações de filmes nacionais e internacionais.

\section{Ciclo do Recife}

O Ciclo do Recife aparece na conjuntura de ciclos regionais de cinema que ocorreram em algumas regiões do país durante a década de 1920. Gomes (1980) afirma que, em 1923, filmes eram produzidos em Campinas, Recife, Belo Horizonte, Rio Grande do Sul e em algumas cidades do interior mineiro. Em pesquisa recente, Araújo (2018) comenta que a produção recifense engloba cerca de cinquenta títulos de enredo (filmes de ficção) ou títulos naturais (filmes documentários) produzidos entre 1923 e 1930. Esse conjunto de películas é considerado por Cunha (2008) como o maior ciclo regional das primeiras décadas do século passado.

O Ciclo do Recife contou com "17 diretores que faziam parte de um grupo de cerca de 40 jovens atraídos pela realização cinematográfica" (CUNHA, 2010, p.90). Para Bernardet (1970, p.8) entre os participantes do cinema do Ciclo estavam "jornalistas, pequenos funcionários, comerciários, operários, artesãos, atletas, músicos populares, atores de teatro; ou apenas não tinham profissão nenhuma".

Os jovens eram fãs de cinema, desde o início do star system norte-americano. Assim, o meio cinematográfico era uma forma de simular o sonho da vida burguesa das cidades e ao mesmo tempo participar das transformações do mundo moderno. Apesar das revistas e jornais do período também terem contribuído com a representação da modernidade mediante a sociedade recifense, o cinema colaborou mais explicitamente na exibição dos novos padrões de vida adotados. (CUNHA, 2010)

No Ciclo do Recife, grande parte das películas remanescentes utilizam a linguagem gráfica na amplitude indicada por Aragão (2006) numa combinação dos modos de simbolização, como podemos perceber nas imagens (figura 6) de Jurando vingar (1925) e Revezes... (1927).
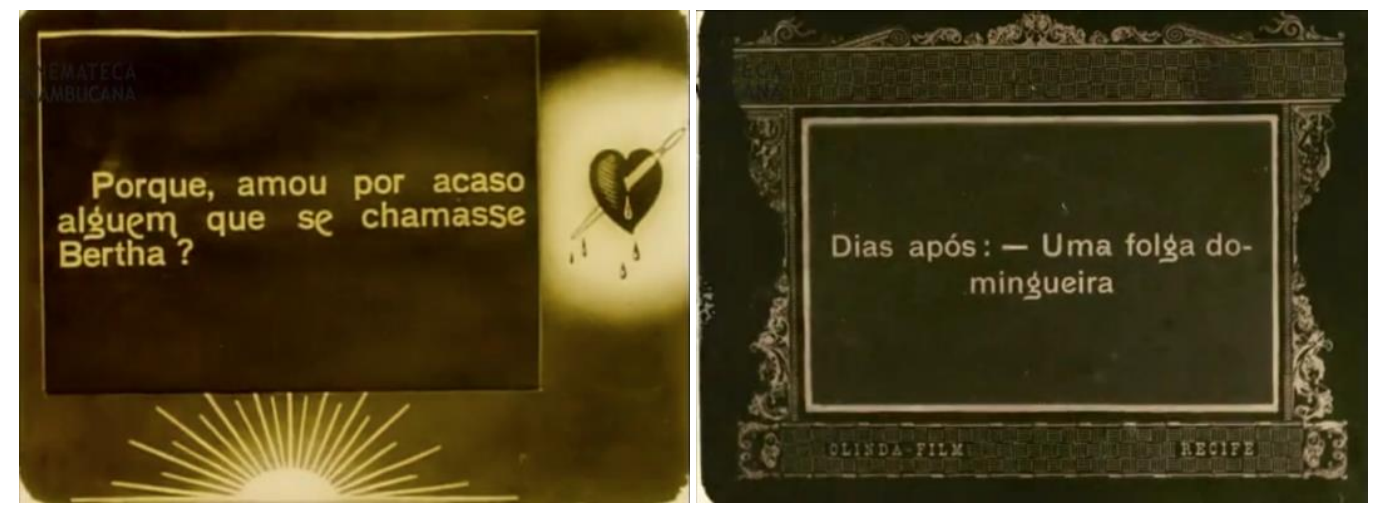

Figura 6: Cartelas de Jurando vingar e Revezes... Fonte: Cinemateca Pernambucana.

Por outro lado, filmes clássicos internacionais lançados no mesmo período - O encouraçado Potemkin (1925), de Sergei Eisenstein, e Sally of the Sawdust (1925), de D.W. Griffith - narram 
suas histórias com letreiros compostos apenas com palavras num fundo preto. Segundo Cunha (2010),

é possível que no processo de absorção da linguagem do cinema europeu e americano na periferia do capitalismo, tenha havido um intervalo médio de vinte anos para que certas figuras retóricas fossem vistas e compreendidas e finalmente empregadas na produção final. (ibid., p.195)

Embora a maioria das ilustrações dos letreiros dos filmes analisados estejam relacionadas semanticamente com as narrativas fílmicas, conforme explorado a seguir, sua incorporação deve ter ocorrido pelo "enriquecimento" comentado por Soares (1951) e a tendência ornamental dos filmes naturais apontada por Araújo (2013a): o uso de truques, efeitos visuais, entre outros, igualmente tinham a aspiração de demonstrar habilidade técnica e linguagem mais artística. Portanto, o uso de ilustrações e molduras, que pode ser interpretado como atraso estético em relação ao cinema internacional; na verdade, significava no contexto do Ciclo do Recife um esforço de produção para valorizar a película aos modos de seus produtores.

\subsection{Aitaré da praia}

Aitaré da praia, dirigido por Gentil Roiz, se passa em sua maior parte no litoral, especificamente na praia fictícia de Tatiá (atual praia de Piedade em Pernambuco). Durante o melodrama, é contada a história de amor proibido entre Cora (Almery Steves) e Aitaré (Ari Severo). O pobre pescador Aitaré é impedido de se relacionar com Cora devido às suas condições econômicas e aos seus antepassados.

Ao mesmo tempo em que declara-se a favor dos costumes do campo, o filme não deixa de expressar as mudanças relacionadas à modernização capitalista na periferia do progresso. Conforme Araújo (2013b, p. 19), "em Aitaré da Praia a cidade se coloca como espaço não só da modernidade como também da reformulação da tradição, ajustando-a aos novos tempos."

As cartelas de Aitaré da praia são parte essencial do filme e funcionam em complementaridade com as imagens filmadas (figura 7). Ao longo de sua duração, a película conta com a presença de 108 exemplares com uma combinação de texto, desenhos (elementos pictóricos) e molduras (elementos esquemáticos). As ilustrações apresentadas nas cartelas, por exemplo, funcionam como uma forma de releitura e reforço para algumas cenas apresentadas no filme.
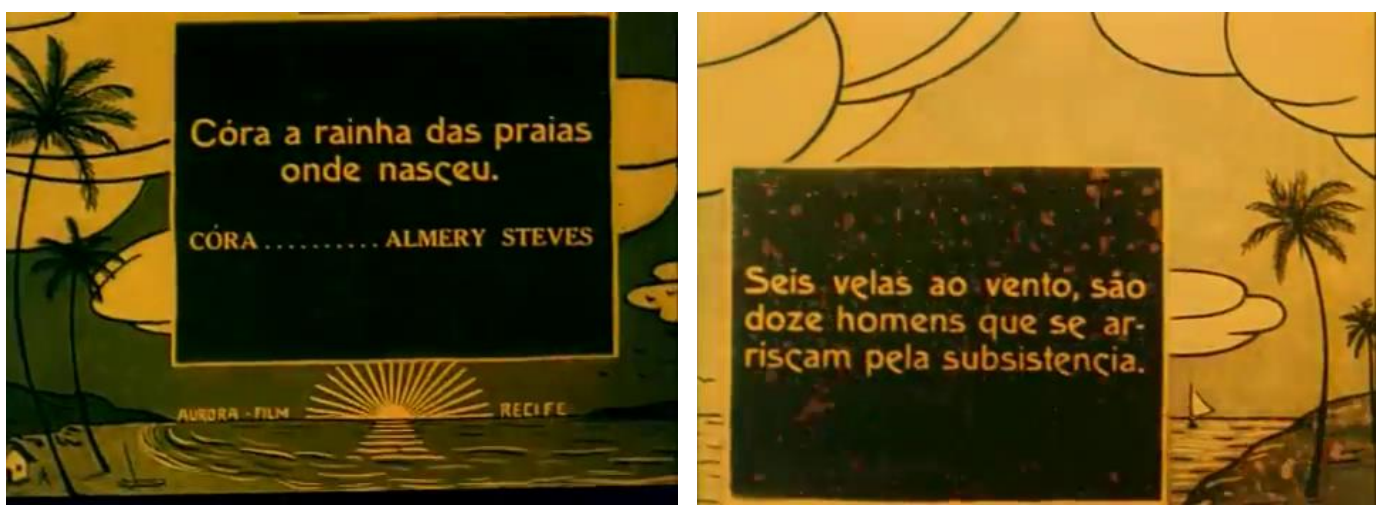
Figura 7: Cartelas de Aitaré da praia com todos os modos de simbolização. Fonte: Cinemateca Pernambucana.

\subsubsection{Elementos pictóricos nas cartelas}

No que concerne ao conteúdo dos elementos pictóricos, as ilustrações das cartelas contribuem para reforçar ideias de regionalismo na película. Cunha (2010, p. 116) informa que "algumas pinturas de Mário Nunes podem ser comparadas a enquadramentos de Aitaré da Praia. O estilo de Mário Nunes é modelo para planos do Ciclo do Recife". Como as ilustrações de Fininho fazem referência às paisagens litorâneas exaltadas no filme, elas contemplam de alguma maneira o estilo do pintor (figura 8).
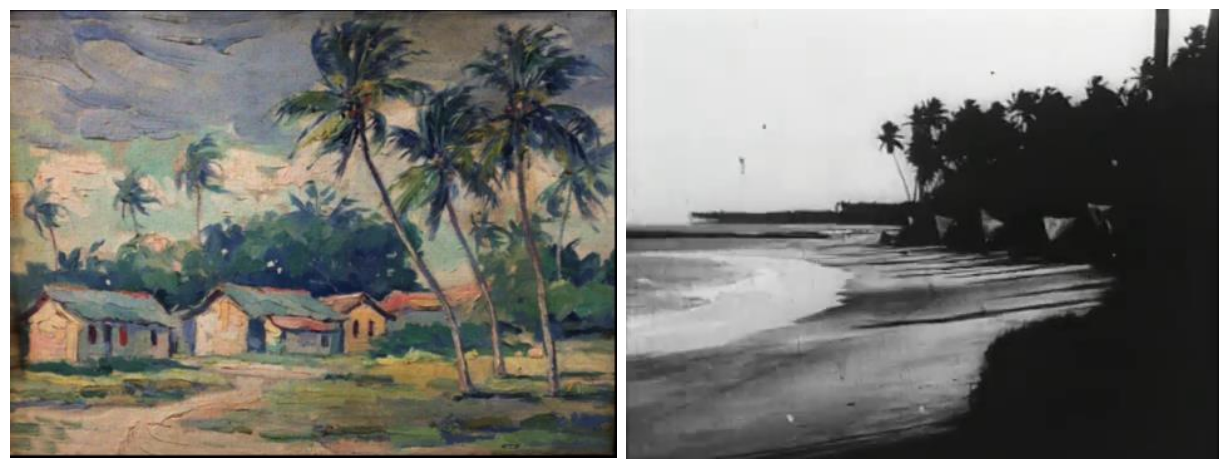

Figura 8: Pintura de Mário Nunes de paisagem litorânea e enquadramento em Aitaré da praia. Fonte: acervo Arte Maior Leilões e Cinemateca Pernambucana.

Ao todo são apresentadas cinco ilustrações durante o filme, todas produzidas e assinadas por Fininho. As três primeiras ilustrações (figuras 9, 10 e 11), que aparecem em 60 cartelas do filme, representam o ambiente litorâneo da praia isolada de Tatiá, onde vivem Cora e Aitaré. As outras duas ilustrações apresentam, respectivamente, o ambiente urbano (3 cartelas), que é representado por prédios e bondes, em referência ao momento em que Aitaré se encontra na cidade (figura 12); e a casa onde Cora vai morar (4 cartelas) após se mudar para Recife (figura 13).
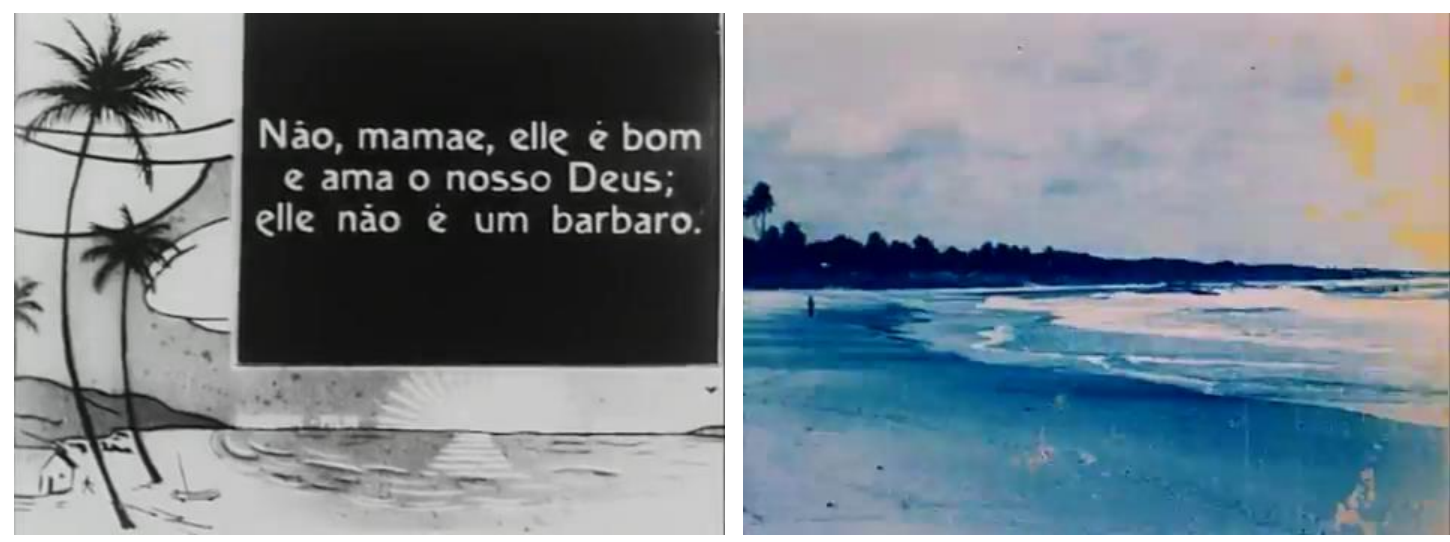

Figura 9: Cartela com ilustração de cena litorânea em Aitaré da praia e imagem do filme. Fonte: Cinemateca Pernambucana. 

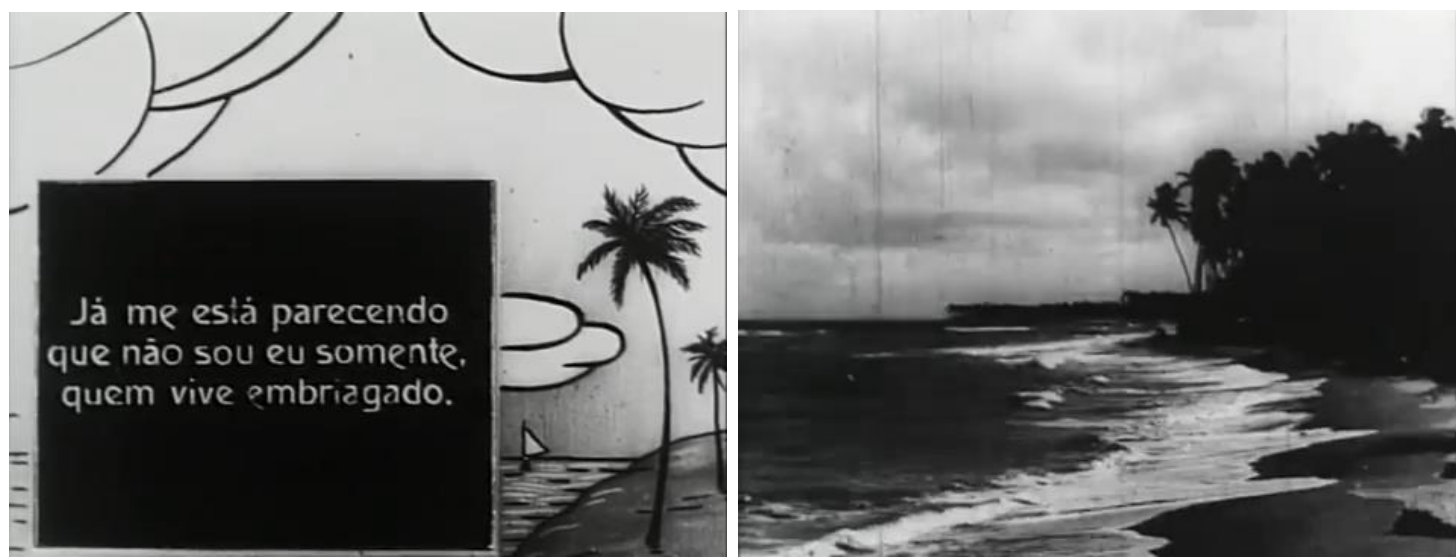

Figura 10: Cartela com ilustração de cena litorânea em Aitaré da praia e imagem do filme. Fonte: Cinemateca Pernambucana.
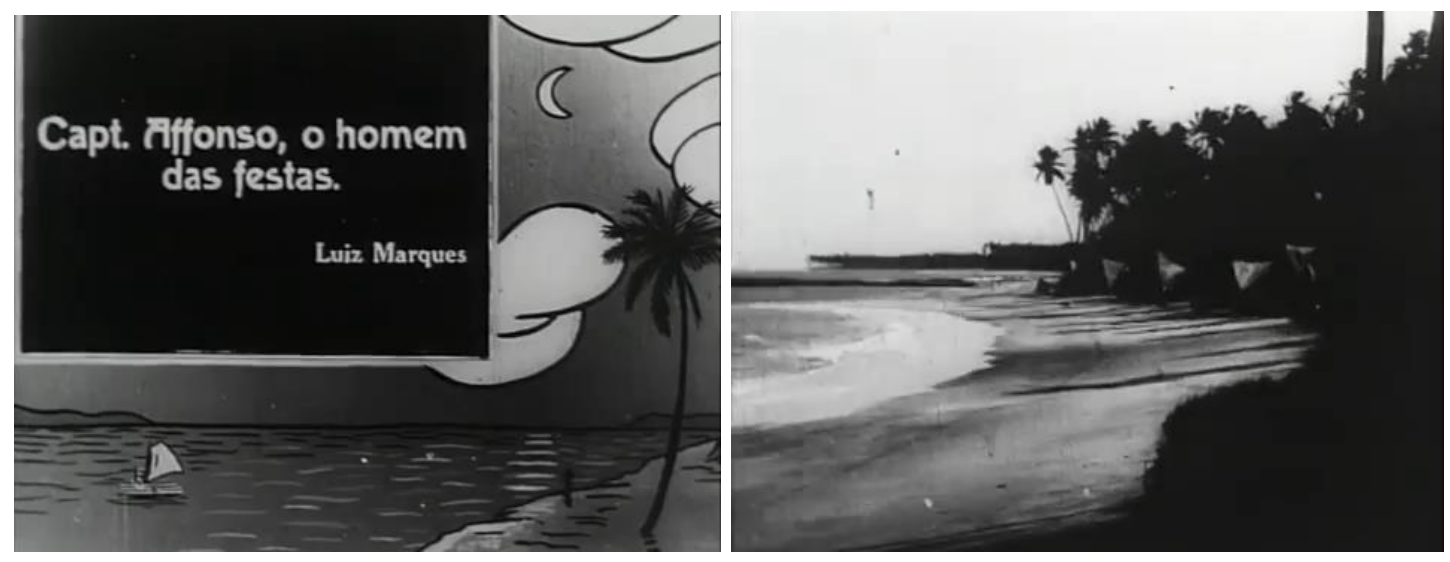

Figura 11: Cartela com ilustração de cena litorânea em Aitaré da praia e imagem do filme. Fonte: Cinemateca Pernambucana.
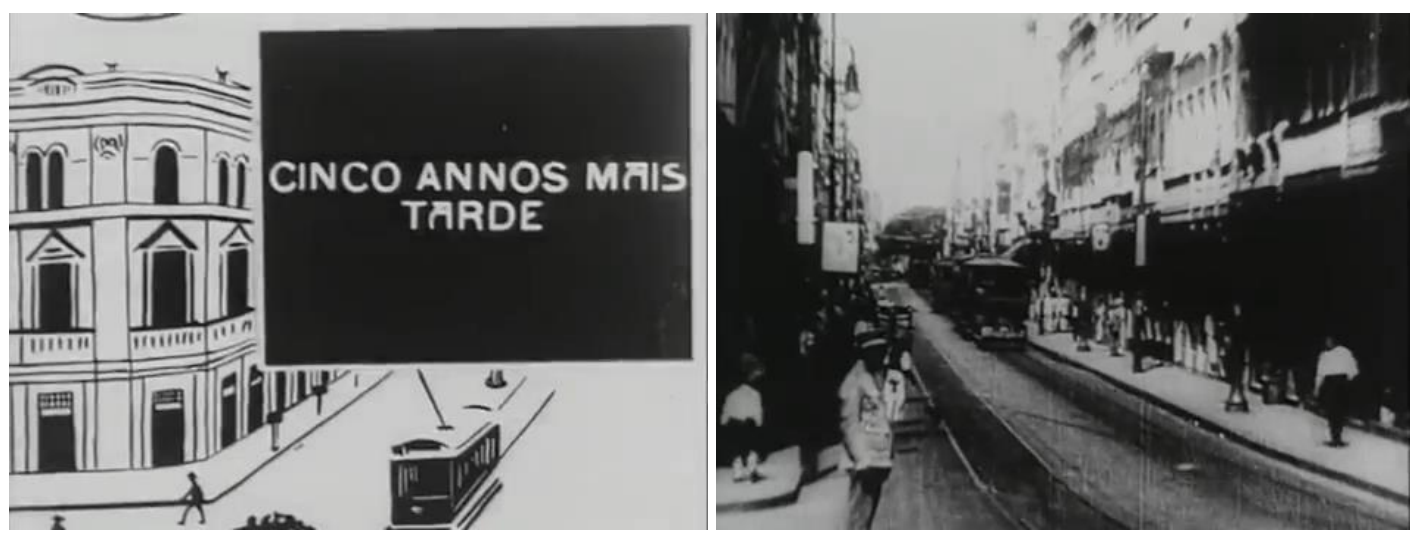

Figura 12: Cartela com ilustração de cena urbana em Aitaré da praia e imagem do filme. Fonte: Cinemateca Pernambucana. 


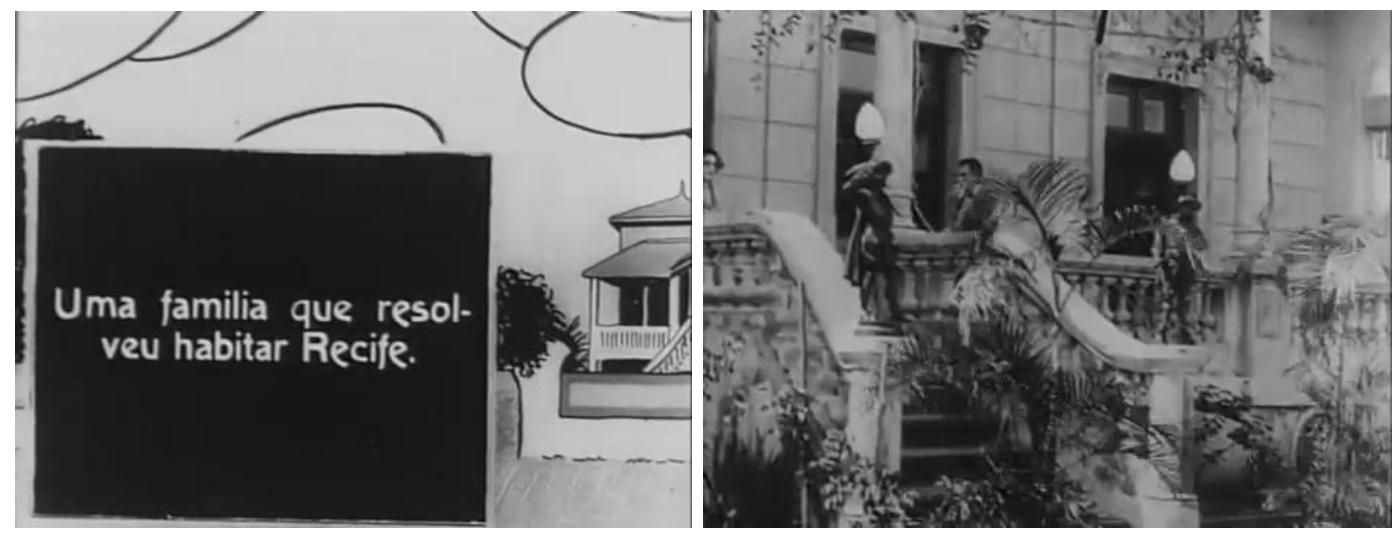

Figura 13: Cartela com ilustração de cena da casa de Cora em Aitaré da praia e imagem do filme. Fonte: Cinemateca Pernambucana.

A maioria das ilustrações reforçam a ideia de nacionalismo regional, com os coqueiros, o mar e o ambiente simples. Desta forma esses elementos gráficos, em conjunto com alguns textos apresentados nos letreiros, também colaboram com a transmissão da temática principal do filme. Afora isso, as ilustrações ajudam a reforçar a ambientação de cada cena, pois as cartelas que aparecem entre cenas na praia, por exemplo, figuram ilustrações do litoral. Nas comparações das figuras acima é possível perceber algumas semelhanças entre as ilustrações com as imagens de cenas próximas.

Dessa forma, podemos concluir que os elementos gráficos pictóricos das cartelas são utilizados de maneira expressiva de acordo com a narrativa, assim como os demais elementos fílmicos. Na transição de Aitaré para a cidade, por exemplo, as cartelas mostram uma ilustração de um prédio e de um bonde, implicando a mudança de ambiente.

Os desenhos têm um estilo semelhante às obras que Fininho produziu para o Jornal do Recife, comentadas anteriormente. Quatro das ilustrações apresentam sombreamento no fundo, formando uma espécie de dégradé. Entretanto, mesmo que uma das ilustrações não apresente este fundo sombreado, ainda é possível ver uma unidade de estilo no conjunto.

As ilustrações de Aitaré da praia são consistentes no estilo e apresentam uma forma de representação não realista com contorno limpo e sem muitas hachuras. As paisagens ilustradas também se encontram distantes ao olho do observador, como em um plano geral, provavelmente, para que a paisagem fosse apreciada e exaltada, assim como nas pinturas litorâneas de Mário Nunes.

A ilustração que representa o ambiente urbano (figura 12) da cidade do Recife se distingue das demais no que se refere ao uso do sombreado e acabamentos, talvez por ser a mais representativa do ambiente citadino e a modernidade. Essa característica pode ser explicada pelas palavras de Araújo (2013b, p. 15): "ao contrário do litoral que precisa ser enaltecido por meio de belas paisagens e por planos de teor documental, o espaço urbano dispensa uma construção mais incisiva. É como se seu valor estivesse dado de antemão".

Como os elementos de exaltação ao litoral e ao regionalismo estão em todo o filme, as configurações gráficas ajudam a reforçar esse contexto. Esse paralelo entre as duas realidades são pontos principais para entender o conteúdo dos elementos pictóricos das cartelas de Aitaré da praia. 


\subsection{A filha do advogado}

O foco da narrativa de A filha do advogado, dirigido por Jota Soares, é todo no espaço urbano. $\mathrm{Na}$ trama, Heloísa é filha do advogado Paulo Aragão que também possui outro filho, Helvécio Aragão. A sociedade reconhece apenas a filiação de Helvécio, que também desconhece a irmã. No filme, ele é retratado como um dândi impulsivo e irresponsável, já Heloísa mora distante da cidade com sua mãe e tampouco sabe da existência do irmão. Antes de partir para uma viagem à Europa, Paulo Aragão pede ajuda ao jornalista Lúcio, que também é seu primo, para transferir sua filha de cidade. Heloísa passaria então a morar no Recife.

A filha do advogado apresenta o reforço do que seria uma cidade em progresso em vários momentos, com cenas (figura 14) que contemplam a cidade do Recife e o seu início de modernidade.
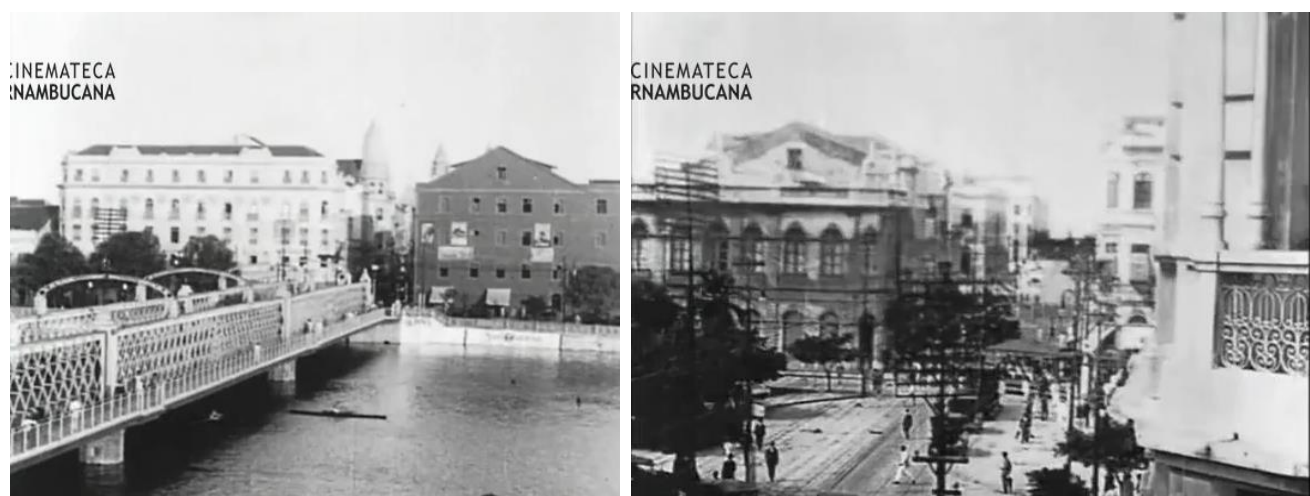

Figura 14: Imagens da cidade do Recife em A filha do advogado. Fonte: Cinemateca Pernambucana.

No que diz respeito às cartelas, as 96 incidências encontradas no filme podem ser divididas em 60 cartelas de diálogo e 36 cartelas informativas. Elas apresentam, em sua maioria, o uso em conjunto de dois elementos das configurações gráficas (figura 15): elementos pictóricos e elementos verbais.

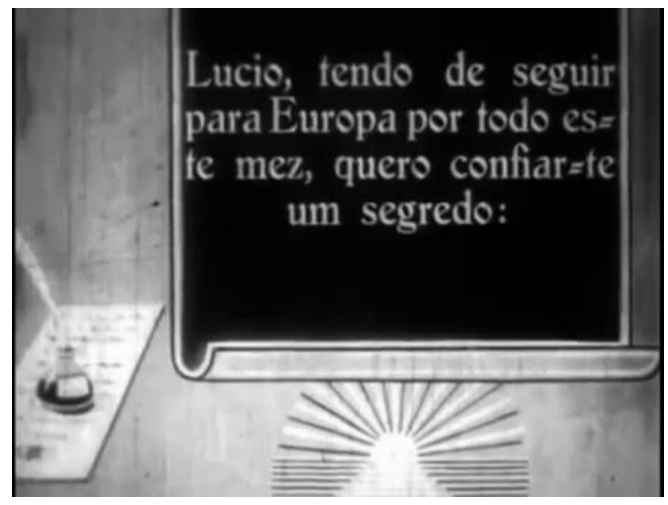

Figura 15: Cartela de $A$ filha do advogado com todos os elementos das configurações gráficas. Fonte: Cinemateca Pernambucana. 


\subsubsection{Elementos pictóricos nas cartelas}

A primeira das ilustrações a aparecer na película (figura 16) é a imagem de um papel com seu conteúdo preenchido por linhas e um tinteiro com bico de pena sobre ele, além do desenho de um sol representando a Aurora-Film, a produtora responsável. Por ser a cartela mais frequente do filme (56 ocorrências), percebemos que ela não tem relação direta com as cenas, mas com a temática geral da narrativa, pois o papel e o tinteiro podem ser relacionados ao advogado Paulo Aragão e ao jornalista Lúcio Novaes.

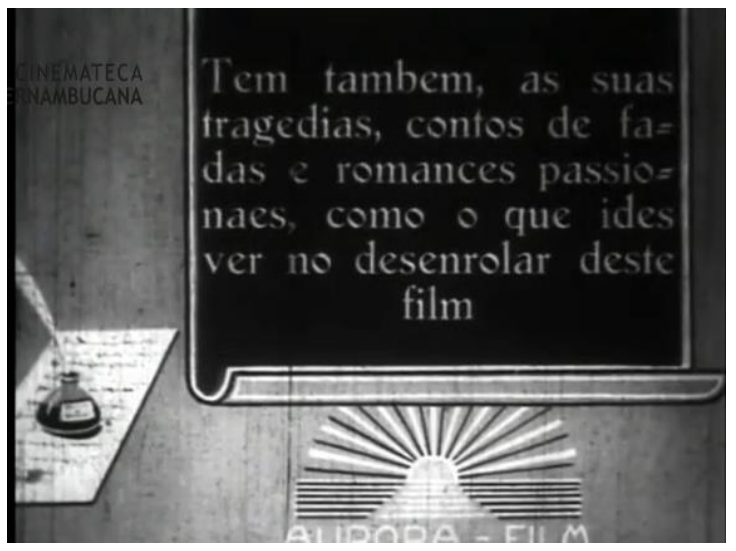

Figura 16: Cartela com ilustração de um papel e um tinteiro em A filha do advogado. Fonte: Cinemateca Pernambucana.

A segunda ilustração (figura 17) exibe a casa no interior onde Heloísa e a mãe vivem, assim como o trem e a estação de Socorro onde Lúcio Novaes e Paulo Aragão desembarcam. A imagem representa uma paisagem, visualizada em um plano geral. Todas as cenas referentes às conversas iniciais de Paulo Aragão com sua filha e as cenas em que Lúcio vai se encontrar com ela são acompanhadas por essa cartela, que também aparece para indicar um procedimento de flashback em certo momento. Nesse flashback, Heloísa lembra que seu pai the entregou uma arma para caso ela precisasse. Sobre essa cartela, também podemos fazer referências aos padrões morais da época pelo fato de Heloísa viver escondida da sociedade nesta casa distante.
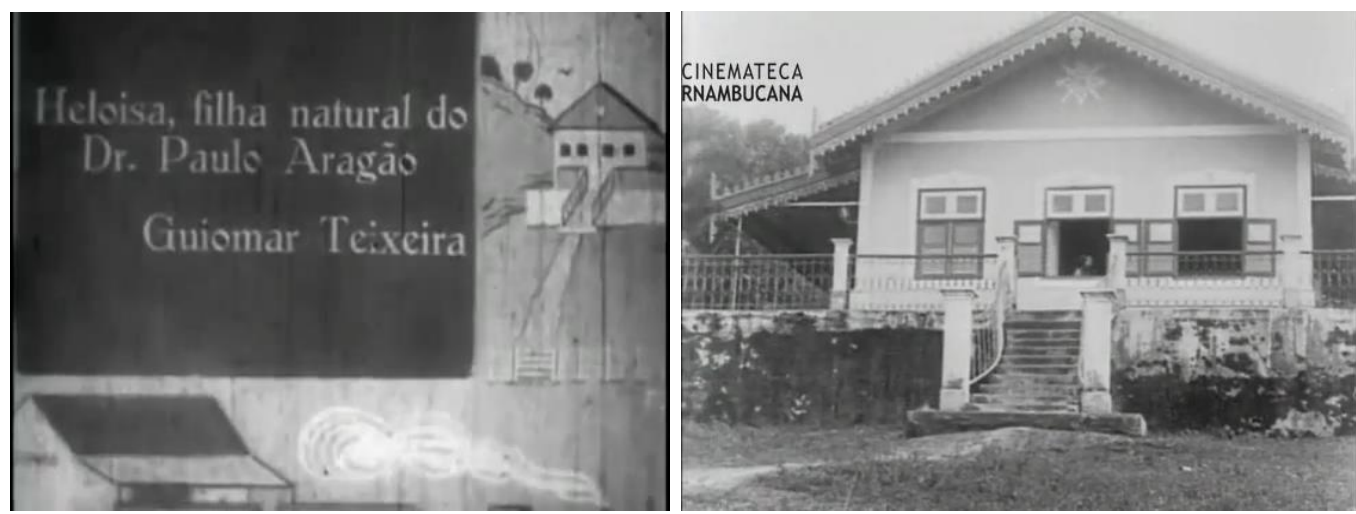

Figura 17: Cartela com ilustração da fazenda onde mora Heloísa em $A$ filha do advogado e cena do filme. Fonte: Cinemateca Pernambucana. 
A terceira ilustração (figura 18) apresenta o baile com vários casais dançando, em um plano geral, no que seria o Clube Pernambucano, que em notícia de jornal no filme é tratado como um cabaré. Pela postura dos dançarinos, os desenhos também têm a intenção de apresentar os movimento da dança. Nessa ilustração os personagens se encontram com o rosto desenhado em perfil, característica que encontramos em outras caricaturas de Fininho.
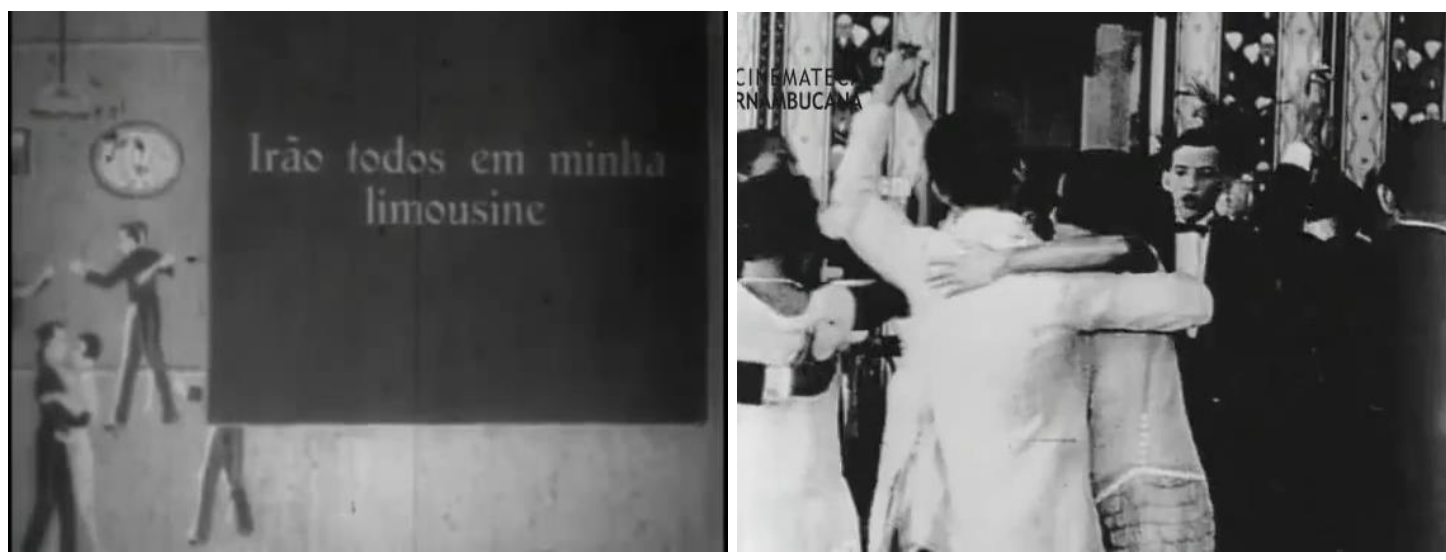

Figura 18: Cartela com ilustração do baile em A filha do advogado e cena do filme. Fonte: Cinemateca Pernambucana.

Além da presença da modernidade através da representação do baile, este elemento pictórico também apresenta questões morais, já que Helvécio, frequentador assíduo, era visto como um homem libertino e causador da desordem. Apesar disso, ainda era respeitado na sociedade por conta de suas posses. Vale lembrar que o mesmo tratamento de privilégios não era dado a Heloísa.

A quarta ilustração (figura 19) revela a cena em que Heloísa depõe na delegacia pelo assassinato de Helvécio. A cartela exibe, numa visão mais aproximada em plano médio, a protagonista sentada dando seu depoimento. Na ilustração também podemos observar alguns detalhes da delegacia e Heloísa com a cabeça abaixada, como que em posição de mocinha indefesa, também representada com seu rosto em perfil. $O$ preenchimento do desenho da personagem também se assemelha ao preenchimento chapado que Fininho aplicou em seus outros desenhos.
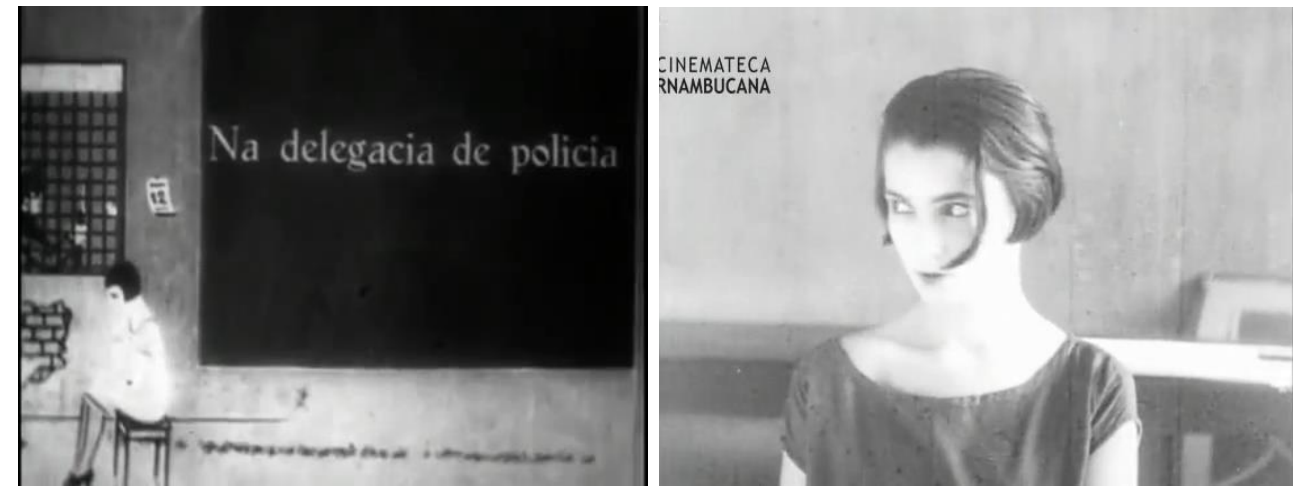

Figura 19: Cartela com ilustração da cena em que Heloísa está na delegacia em A filha do advogado e cena do filme. Fonte: Cinemateca Pernambucana. 
A roupa de melindrosa que o Heloísa veste no filme, e consequentemente na ilustração, é típica dos anos 1920. A figura da melindrosa aparece com frequência nas revistas do período (figura 20), como na capa da revista Rua Nova, de 11 de setembro de 1926, e na capa da Revista da Cidade, de 15 de janeiro de 1927. Sobre as melindrosas nos filmes do Ciclo, Cunha (2010, p. 168) aponta que os filmes "vão usar a figura da melindrosa de maneira muito especial. Não à toa, evidentemente: a moça de maneiras afetadas e roupas extravagantes é a mulher da cidade, do consumo, da loja de roupas, clientes das figurinistas".
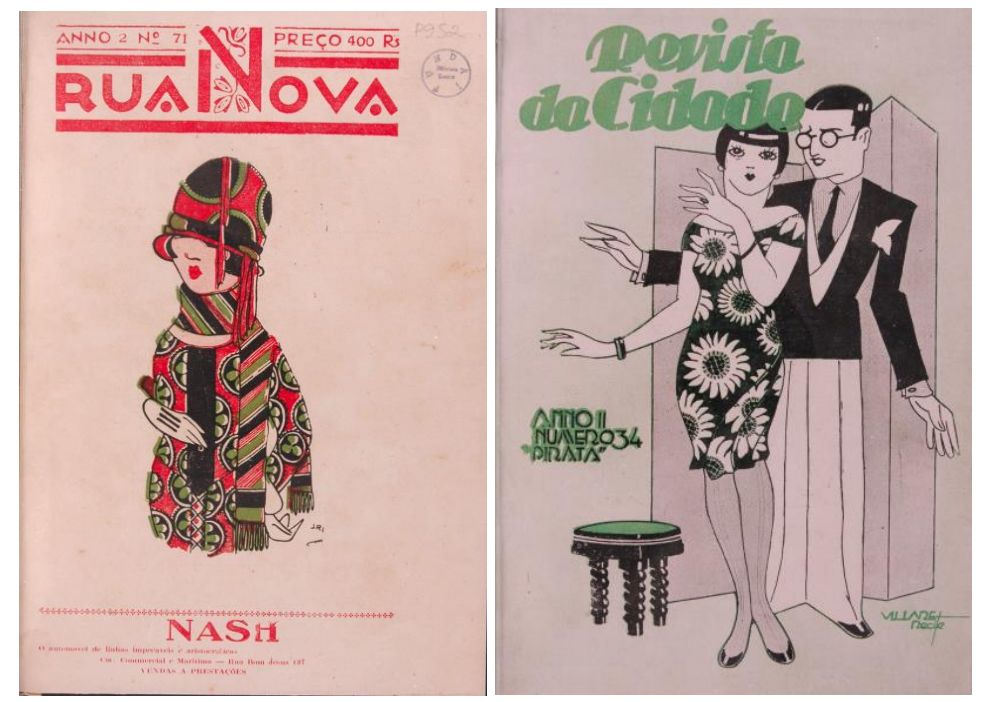

Figura 20: A figura da melindrosa nas capas de revistas. Fonte: Portal Domínio Público.

A última ilustração (figura 21) representa o julgamento de Heloísa. Na imagem, um plano geral do tribunal exibe Heloísa, o juiz e o público. Esse desenho pode ser visto como um reforço da dualidade entre a modernidade e as questões morais. Heloísa é acusada de assassinar Helvécio e durante o julgamento é apontada como uma "gatuna de noivos". A cena de julgamento e a posição do juiz que aponta o dedo para a mocinha é simbólico dessa dualidade. Embora a cidade fosse moderna, Heloísa ainda tem que defender a sua honra. Os dois personagens centrais da cartela também estão representados com o rosto em perfil e o preenchimento do desenho é chapado, em consistência com os outros desenhos de Fininho.
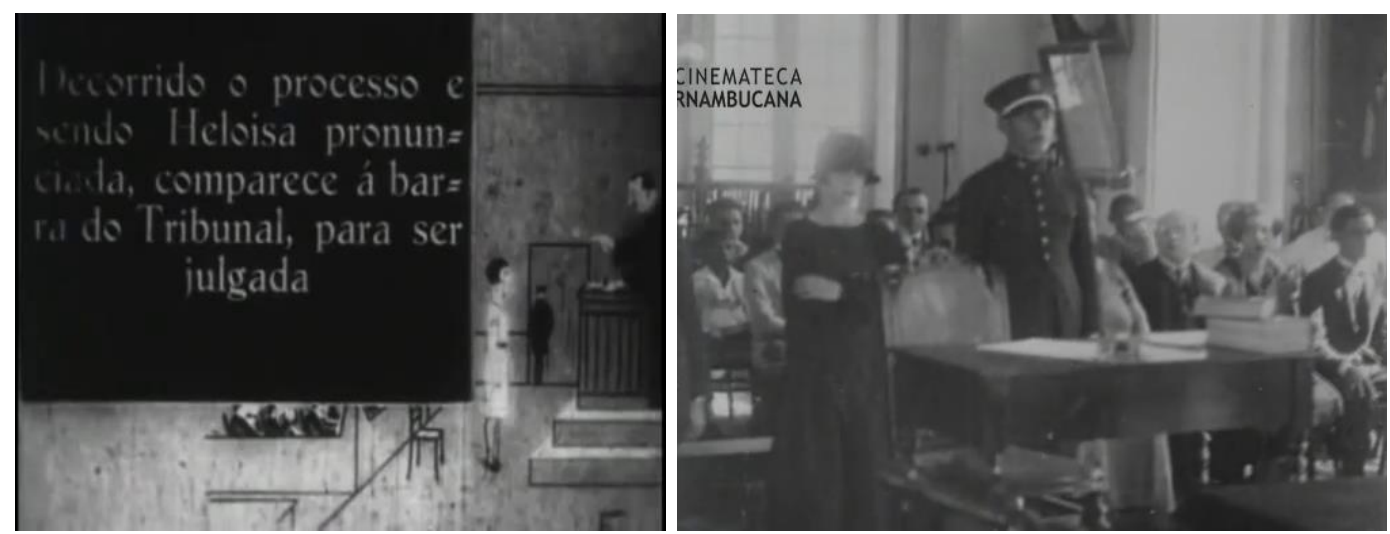

Figura 21: Cartela com ilustração da cena do julgamento de Heloísa em A filha do advogado e cena do filme. Fonte: Cinemateca Pernambucana. 
A maioria dos elementos gráficos pictóricos de A filha do advogado se apresentam de acordo com o momento em que o filme se encontra, fazendo referência aos acontecimentos que se apresentam em paralelo. A única exceção é a cartela do papel com o tinteiro (figura 16) que é usada genericamente em momentos diferentes sem ligações com as cenas.

Os desenhos das cartelas também foram feitos por Fininho, como em Aitaré da praia. Porém, eles têm o diferencial da representação de pessoas em tamanhos reduzidos, com preenchimento e algum sombreado no cenário. Já os personagens apresentam feições e traços simples, apresentados em perfil. Percebemos pelas formas que não existia a preocupação de apresentar uma ilustração mais realista e, sim, uma síntese gráfica, assim como nas caricaturas.

\section{Conclusões}

O Ciclo do Recife foi um movimento de produção cinematográfica que ocorreu na capital pernambucana durante os anos 1920. Sua beleza, conforme afirma Cunha (2010), no que concordamos, está na vontade do grupo em produzir cinema em uma cidade que estava na periferia do capitalismo, apesar de todas as dificuldades. Ademais, recém-descobrindo as mudanças promovidas pelo progresso, Recife via suas avenidas e ruas se expandindo ao mesmo tempo em que a economia açucareira declinava. No meio disso tudo, Gilberto Freyre defendia seu modernismo regionalista, evocando as tradições nordestinas.

Assim, o cinema era uma forma de o grupo de realizadores se inserir nesse progresso, proporcionado pelas cenas feitas em casarões e carros emprestados pela alta burguesia recifense. A modernidade aparece nos filmes como parte de um desejo do grupo de fazer parte desse processo.

A pesquisa histórica nos proporcionou compreender uma parcela da trajetória profissional do artista gráfico Fausto Silvério Monteiro. Para além das ilustrações exibidas em Aitaré da praia e A filha do advogado, Fininho teve uma carreira reconhecida no circuito artístico e cultural recifense ao colaborar com periódicos locais e exibir seus trabalhos em exposições. A prestação de serviço gráfico para o cinema do Ciclo do Recife faz do artista um dos pioneiros do design a exercer essa atividade em Pernambuco embora o termo ainda não existisse no país.

Sobre os elementos pictóricos das cartelas, os personagens são simplificados e desenhados com o rosto em perfil, como a maioria das caricaturas e ilustrações de personagens do artista, e as demais temáticas apresentam contorno, preenchimento chapado, sombreado e texturas no fundo.

Portanto, o uso e a consistência dos desenhos nas cartelas de ambos os filmes são tanto fruto da autoria do mesmo artista quanto de uma preocupação estética dos produtores. Mesmo datadas aos olhos do cinema estrangeiro do período, os letreiros ilustrados por Fininho demonstram um esforço e valorização da produção fílmica recifense, seguindo sua tendência ornamental.

Os elementos pictóricos das cartelas dos dois filmes são coerentes com os ideais modernos da época, em especial, aqueles que apontam diretamente para figuras que se relacionam com o progresso da cidade, como prédios, bonde e a melindrosa. Da mesma forma, questões regionais 
também eram apresentadas na medida em que os filmes tratavam de temáticas locais, como a vida no litoral ou o posicionamento da mulher na sociedade.

Ao apresentarmos os trabalhos gráficos de Fininho, pretendemos contribuir tanto para a história do cinema quanto do design pernambucanos do começo do século XX. Assim, entendemos como de grande valor a investigação de seus trabalhos e da relação do artista com as produções em torno do movimento.

\section{Referências}

ARAGÃO, Isabella Ribeiro. A dimensão gráfica do cinema: uma proposta de classificação de suas configurações. Dissertação (Mestrado em Design) - Universidade Federal de Pernambuco, Recife, 2006.

ARAÚJO, Luciana Côrrea de. Os encantos da Veneza Americana e da propaganda pelo cinema: os filmes financiados pelo governo Sergio Loreto em Pernambuco (1922-1926). Estudos Históricos (Rio de Janeiro), v. 26, p. 94-112, $2013 \mathrm{a}$.

Tensões, idealizações e ambiguidades: as relações entre campo e cidade no cinema em Pernambuco nos anos 1920. Imagofagia: Revista de la Asociación Argentina de Estudios de Cine y Audiovisual, Argentina, 2013b.

BARROS, Souza. A década 20 em Pernambuco. Recife: CEPE Editora, 2015.

BERNARDET, Lucilla. Cinema Pernambucano de 1922 a 1931: primeira abordagem. Dissertação (Mestrado em Teoria Literária e Literatura Comparada) - Universidade de São Paulo, São Paulo, 1970.

CINEARTE. Rio de Janeiro, 1926-1942. Disponível em: http://hemerotecadigital.bn.br/acervo-digital/cinearte/162531. Acesso em: 09 jul. 2021.

CUNHA, Paulo Carneiro da. A utopia provinciana: Recife, cinema, melancolia. Recife: Ed. Universitária da UFPE, 2010.

Tempo, filme, memória: a invenção do passado em Aitaré da Praia. FAMECOS: Mídia, Cultura e Tecnologia, Porto Alegre, v. 15, n. 36, 2008. Disponível em: $\mathrm{http} / / /$ revistaseletronicas.pucrs.br/ojs/index.php/revistafamecos/issue/view/316. Acesso em: 22 mai. 2020.

DIÁRIO DA MANHÃ. Recife, 1 dez. 1935. Disponível em: http://200.238.101.22/docreader/DM1935/4205. Acesso em: 12 jul. 2021.

DIÁRIO DE PERNAMBUCO. Recife, 1825- . Disponível em: http://bndigital.bn.br/hemeroteca-digital/. Acesso em: 09 jul. 2021.

JORNAL DO RECIFE. Recife, 1859-1938. Disponível em: http://bndigital.bn.br/hemerotecadigital/. Acesso em: 09 jul. 2021.

JORNAL PEQUENO. Recife, 28 mar. 1933, p.4. Disponível em: http://bndigital.bn.br/hemeroteca-digital/. Acesso em: 09 jul. 2021.

MACHADO, Helena. Design \& cinema: an analysis of the graphic language as a narrative strategy in Hollywood's contemporary films. Dissertação (Mestrado) - Escola Superior de Artes e Design, Porto, 2020.

METZ, Christian. Linguagem e cinema. Tradução de Marilda Pereira. São Paulo: Perspectiva, 1980.

NASCIMENTO, Luiz. História da imprensa pernambucana VIII. Recife: Editora Universitária, 1982. 
OLIVEIRA, Larissa. A dimensão gráfica nos filmes do Ciclo do Recife: Aitaré da praia e A filha do advogado. 222 p. Dissertação (Mestrado em Design) - Universidade Federal de Pernambuco, Recife, 2020.

REVISTA DO NORTE, 9 out. 1923. Disponível em: https://www.fundaj.gov.br/index.php/publicacoes-digitalizadas/10034-revista-do-norte. Acesso em: 09 jul. 2021.

SOARES, Jota. Subsídios para história do cinema pernambucano. Notícias de Pernambuco. Recife, ano 1, n.3, abri. 1951, p.32-38.

TWYMAN, Michael. A schema for the study of graphic language. Processing of visible language, v. 1, p. 117-150, 1979.

Using pictorial language: a discussion of the dimensions. In: DUFTY, Thomas; WALLER, Robert (Eds.). Designing usable text. Florida: Academic Press, 1985. p. 245-312.

WANDERLEY, Andrea C. T. Fotográfica. O "artista fotógrafo" Louis Piereck (1880 1931). 15 dez. 2020. Disponível em: <https://brasilianafotografica.bn.gov.br/?p=20730〉. Acesso em: 09 jul. 2021.

\section{Sobre as autoras}

\section{Larissa Constantino}

Larissa Constantino é graduada em Design, com período sanduíche pela NSCAD University, e mestre em Design pela UFPE. Sua dissertação de mestrado teve como tema a linguagem gráfica do cinema pernambucano do Ciclo do Recife. Atualmente trabalha como diretora de arte e motion designer.

https://orcid.org/0000-0001-6693-6184

\section{Isabella Ribeiro Aragão}

Isabella Ribeiro Aragão é graduada em Desenho Industrial - Programação Visual e mestre em Design pela UFPE, doutora em Arquitetura e Urbanismo pela USP com período sanduíche na UAL - Central Saint Martins. Atualmente é Professora Adjunta do Departamento de Design da UFPE, lecionando nos cursos de graduação e pós-graduação, e co-liderando o Laboratório de Práticas Gráficas (LPG).

https://orcid.org/0000-0002-4407-3565 